\title{
COLECCIONISMO Y PATROCINIO DE ARTE EN EL SIGLO XVII: EL EJEMPLO DE LA FAMILIA MUÑOZ DE OTÁLORA.
}

\section{COLLECTING AND SPONSORSHIP OF ART IN THE 17TH CENTURY: THE EXAMPLE OF THE FAMILY MUÑOZ DE OTÁLORA.}

\author{
José Antonio Martínez Martínez \\ Universidad de Murcia
}

\section{RESUMEN}

En este artículo se pretende ilustrar el auge del coleccionismo y del patrocinio artístico en el siglo XVII a través del ejemplo concreto que nos proporcionan los inventarios de bienes inéditos del licenciado Alonso Muñoz de Otálora, alcalde de casa y corte, y de Juana Clara Muñoz de Otálora, esposa del licenciado Juan Bautista Muñoz Sáenz de Navarrete, fiscal del consejo de Castilla. El coleccionismo se presenta desde la perspectiva social como una manifestación inherente a las clases privilegiadas y a los grupos de poder, aunque tampoco resulte extraño encontrar notables colecciones de pintura y esculturas en los hogares de los artesanos, comerciantes y oficiales. Interpretamos el coleccionismo como símbolo del estatus social y económico y como una manifestación del prestigio de los individuos y de las instituciones, circunstancia que se evidencia claramente en la colección de pintura y en la biblioteca del licenciado Alonso Muñoz de Otálora. El patrocinio y el mecenazgo artístico se presentan como una herramienta de las élites de poder al servicio de la perpetuación de la memoria del linaje, especialmente a través de la asociación de lo sagrado y lo piadoso con los escudos de armas de la familia.

Palabras clave: Coleccionismo / patrocinio / Iglesia de Nuestra Señora de la Soledad de Caravaca / Muñoz de Otálora / biblioteca.

\section{ABSTRACT}

This article aims to illustrate the rise of collecting and artistic sponsorship in the seventeenth century through the concrete example provided by the inventories of unpublished goods of the lawyer Alonso Muñoz de Otálora, alcalde de casa y corte, and of Juana Clara Muñoz de Otálora, wife of Juan Bautista Muñoz Sáenz de Navarrete. Collecting is presented from the social perspective as an inherent manifestation of the privileged classes and power groups, although it is not strange to find notable collections of paintings and sculptures in the homes of artisans, merchants and officials. We interpret collecting as a symbol of social and economic status and as a manifestation of the prestige of individuals and institutions, a circumstance that is clearly evidenced in the collection of paintings and in the library of Mr. Alonso Muñoz de Otálora. Sponsorship and artistic patronage are presented as a tool of the power elites at the service of the perpetuation of the memory of the lineage, especially through the association of the sacred and the pious with the family's coats of arms.

Keywords: Collecting, sponsorship, Church of Our Lady of Soledad de Caravaca, Muñoz de Otálora, library. 


\section{INTRODUCCIÓN}

El Diccionario de Autoridades define el coleccionismo como "el acto de recoger, o juntar algúna cosa. Y tambien la misma junta que se hace de las que son de una espécie, para que estén unidas". Por tanto, podemos interpretar el coleccionismo como la afición o inclinación de algunas personas a juntar objetos o cosas, así como a la técnica para ordenarlos adecuadamente (Ureña, 1988: 99-148). Existen diversos factores que explican la aparición del afán por el coleccionismo y su auge en el siglo XVII: el poder adquisitivo del coleccionista, la formación cultural del momento y el ambiente social del siglo XVII (Ureña, 1988: 100). El arte se presenta como una manifestación de primer orden del poder económico y político y como un signo inequívoco del prestigio social de los individuos y de las instituciones. El estatus de los individuos se proyecta socialmente a través del mecenazgo, del patronazgo y de la financiación de obras de arte (Illán, 2006: 109-118).

La colección privada del rey actúa como modelo del buen gusto y sirve de imitación normativa para los miembros de la aristocracia y para otros sectores de la población (Colomer, 2004: 123-158), incluidas las élites urbanas y los sectores sociales adscritos a las reales audiencias y a los consejos de la monarquía. Los tratadistas animaron a los monarcas a considerar la pintura como una representación gráfica de sus dominios, atendiendo a criterios estratégicos y propagandísticos y con el fin de conocer y enaltecer sus posesiones y territorios (Jaquero, 2017: 386-396). Los Austrias mostraron especial predilección por las pinturas veneciana y flamenca y ejercieron su mecenazgo con artistas de la talla de Tiziano o Rubens (Colomer 2004: 137). En los círculos aristocráticos se comienza a ver la pintura y su coleccionismo como signo distintivo de prestigio social. La protección y el mecenazgo de las órdenes religiosas permitieron un amplio desarrollo y recorrido de la pintura religiosa (Jaquero, 2007: 391). Las grandes casas nobiliarias y los validos reales protegieron a todo tipo de artistas y fomentaron las artes como un medio publicitario de la magnificencia de la familia y del linaje. La vinculación del artista con el mecenas era entendida como una forma de adscripción a una determinada red clientelar y como un medio idóneo para obtener alguna pensión o algún dinero eventual, permitiendo, del mismo modo, un beneficio recíproco traducido en honor y fama para ambos (Enciso, 2008: 47-61).

Para Gutiérrez de los Ríos el principal objetivo de los pintores era alcanzar la fama, al igual que hicieron los pintores clásicos: la primordial función de la pintura era su capacidad para ensalzar a quienes la practicaban y obtener el deseado reconocimiento social (Jaquero, 2017: 389). Los grandes pintores buscaron la protección de los monarcas y de los aristócratas porque estaban situados en el escalafón más alto del sistema social y contaban con los recursos económicos necesarios para costear los proyectos y proteger las obras y a los artistas. La protección y el mecenazgo regio también sirvió como medio de ascenso social, como bien ilustra el ejemplo de Velázquez (Jaquero, 2017: 396), el cual incluso llegaría a conseguir que se le despachara un hábito de la orden de Santiago.

La posesión de cuadros, especialmente de temática religiosa, era una afición común a todos los grupos sociales y un elemento esencial del adorno de los hogares. En las casas de los maestros sederos y de los mercaderes murcianos, por ejemplo, eran muy abundantes y en algunas ocasiones disponían de obras de gran calidad e incluso de sus propios retratos (Miralles, 2003:146). En el inventario de bienes de Ana García, mujer de Sebastián González, maestro de zapatero, vecinos de la villa de Madrid, se contabilizan un total de once pinturas, todas ellas de carácter religioso. Entre las pinturas inventariadas en el año 1629 encontramos un retrato del Santo Sudario y una tabla grande enmarcada de la Resurrección de Cristo apreciada en sesenta y seis reales ${ }^{1}$. Todos los grupos sociales con los necesarios recursos económicos participaban del coleccionismo de obras de arte en el siglo XVII.

Los consejeros de Castilla también reunieron relevantes colecciones de pintura. Janine Fayard encontró en los inventarios de bienes de estos juristas interesantes colecciones de arte que reunían obras de artistas españoles y extranjeros. Entre los españoles destacan los pintores de la escuela madrileña, aunque tampoco faltaban los pintores de gran renombre

1 Archivo Histórico de Protocolos Notariales de Madrid (en adelante AHPNM). T. 3149, fols. 138r/155. Inventario de bienes de Ana García, mujer de Sebastián González, maestro zapatero. 
como Ribera o Velázquez. También abundaban los artistas italianos, representados por Bassano, Giordano, Rafael, Andrea del Sarto, Tiziano o Tintoretto. Los artistas flamencos están especialmente representados por el Bosco, Rubens o Teniers (Fayard, 1982: 427). Otros miembros de las chancillerías y reales audiencias y de los restantes tribunales del aparato institucional de la monarquía hispánica también practicaron el coleccionismo artístico. Se tiende a considerar que buena parte de estos coleccionadores de obras de arte no seleccionaban las pinturas atendiendo a unos criterios claros, sino que anteponían la uniformidad a sus gustos personales, el prestigio del autor o la valoración de la pieza (Agulló, 2003: 235-248).

En el siglo XVII, época de mayor esplendor del coleccionismo español, se produce una cierta especialización en los gustos de los coleccionistas, momento donde se sitúan el origen y consolidación del coleccionismo moderno, auspiciado por los Austrias (Ureña, 1998: 99-148). Es cierto que los coleccionistas, especialmente los de alta nobleza, se dejaba influenciar por las bogas o modas, especialmente las dimanadas de las colecciones reales, pero también aprovechaban las almonedas y las liquidaciones de bienes para adquirir piezas sueltas o lotes completos de obras. Un buen ejemplo de este tipo de coleccionista lo encontramos en la figura de Alonso Muñoz de Otálora, alcalde de casa y corte, hijo del licenciado Alonso Muñoz, del Consejo de Indias, y hermano de Pedro Muñoz de Otálora, caballero de la orden de Santiago y caballerizo de la Reina, personaje cercano a la camarilla del duque de Lerma. También era hermano de Sancho Muñoz de Otálora, canónigo de la catedral de Toledo. Además, Alonso Muñoz de Otálora mantenía una gran amistad con el licenciado Diego de Alderete, hechura del duque de Lerma, ${ }^{2}$ y con Diego González de Contreras. Asimismo pertenecía al círculo relacional de Diego Sarmiento de Acuña, conde de Gondomar. Es posible que esta cercanía a la corte despertara o estimulara su interés por las obras de arte y por las colecciones de libros. La cuestión es que a lo largo de su trayectoria social consiguió reunir una pequeña colección de pintura y una gran biblioteca.

El presente artículo está estructurado en dos grandes bloques: en primer lugar trataremos sobre las colecciones de obras de arte del licenciado Alonso Muñoz de Otálora, prestando especial atención a su biblioteca y a su colección de pintura. Asimismo, nos detendremos en la importante colección de pintura y de escultura reunida por Juana Clara Muñoz de Otálora, expuesta en sus casas de la villa de Caravaca, encomienda santiaguista de la orden de Santiago. Las casas de los Muñoz de Otálora, situadas en la denominada calle de las monjas, albergaba buena parte de las pinturas y esculturas de la familia, precisamente por este motivo las hemos escogido como eje central de nuestro discurso. En esta primera parte también nos acercaremos al mobiliario y a los ornamentos litúrgico que adornaban las casas y los oratorios de los Muñoz de Otálora de Caravaca, a los objetos de uso cotidiano, a la prendas de vestir, y a las joyas que lucía la familia. Para alcanzar uno de nuestros principales objetivos de estudio -presentar las obras de arte y los adornos personales como símbolos del estatus y de la jerarquía social en siglo XVII- hemos usado una metodología comparada partiendo del inventario y tasación de bienes de Juana Clara Muñoz de Otálora, mucho más extenso y detallado que el del licenciado Alonso Muñoz de Otálora.

En segundo lugar, nos ocuparemos del patrocinio artístico de la familia Muñoz de Otálora, prestando especial atención a la ermita de Nuestra Señora de la Concepción de Singla, construida en el campo de Caravaca, a la denomina ermita de La Reja y a la iglesia de Nuestra Señora de la Soledad. La importancia de este artículo radica en la presentación de una serie de inventarios y tasaciones de bienes inéditos, concernientes tanto a la villa de Caravaca como a la villa y corte de Madrid.

Estamos ante una de las principales familias de poder de la villa de Caravaca en el periodo moderno. Los Muñoz de Otálora monopolizaron desde mediado del siglo XVI los principales oficios del ayuntamiento -incluyendo el oficio de alférez mayor, que quedaría vinculado en los mayorazgos familiares- y consiguieron gracias a una política matrimonial homogámica introducirse en los círculos cortesanos, ejerciendo incluso el empleo de caballerizos de la reina. Su poder económico radicaba especialmente en los negocios ganaderos (abastecimiento de carnes, exportación lanera y cría caballar), en la práctica

2 Alonso Muñoz de Otálora nombraría a Diego de Alderete como su albacea. 
usurera a través de imposiciones de censos y juros y en la propiedad de la tierra, de molinos, almazaras, batanes y mesones. El licenciado Alonso Muñoz, del consejo de Indias, casado con Catalina de Otálora, conseguiría tejer una amplia red relacional gracias a la ayuda de Sancho López de Otálora, su suegro, personaje cercano al círculo del Inquisidor Valdés (Garibay, 1854: 214; Cutillas y Montojo, 1998: 43). Las estrategias matrimoniales homogámicas y consanguíneas practicadas desde finales del siglo XVI propiciaron que la familia consolidara su alianza con la familia Otálora y afianzara su posición en la corte y en las instituciones del aparato institucional de la monarquía hispánica en las siguientes generaciones.

\section{LAS COLECCIONES DEL LICENCIADO ALONSO MUÑOZ DE OTÁLORA}

Alonso Muñoz de Otálora fue colegial y rector del Colegio Mayor de Cuenca. Durante su periodo de estudios disfrutó de la ayuda económica de su hermano ${ }^{3}$. En 1590, tras licenciarse en derecho, fue designado como oidor de la Real Audiencia de Galicia (Fernández, 1982: 127), institución en la cual también sirvió el oficio de alcalde mayor, siendo designado en 1599 por el gobernador y capitán general del Reino de Galicia (Fernández, 1982: 127), para realizar una visita a la Universidad de Santiago de Compostela ${ }^{4}$. Accedió a la Real chancillería de Granada en 1602, ciudad en la que entabló numerosas amistades, entre ellos el licenciado Alonso Núñez de Bohorques, su pariente, que le ayudaron a ampliar notablemente su círculo relacional. En 1604, tras una breve estancia en la Real Chancillería de Granada, sería nombrado como alcalde de casa y corte (Pelorson, 1980: 255), empleo que desempeñaría hasta su fallecimiento en 1606 y en cuyo ejercicio practicaría los famosos interrogatorios y diligencias con motivo de la denuncia formulada contra Cervantes y su entorno en la noche del diez de mayo de 1605 (Mainez, 1901: 407; Astrana, 1958: 102).

Los alcaldes de casa y corte mantenían una estrecha relación con el Consejo Real, abarcando sus jurisdicciones al espacio que dejaron la ausencia de las chancillerías y de las reales audiencias (Ezquerra, 2015:1965), ejerciendo la primera instancia en el ámbito civil y la "suprema jurisdicción criminal en el ámbito penal, sin apelación sino ante ellos mismos" (Ezquerra, 2015:1967). La mayor parte de los alcaldes entendían su oficio como un trampolín para ascender a las salas de los consejos o a las presidencias de las chancillerías (De la Guardia, 1994: 56). Un ejemplo: Gregorio López de Mendizábal, caballero de la orden de Santiago, casado con la sobrina del licenciado Alonso Muñoz de Otálora, ejerció como fiscal y oidor de la chancillería de Granada y de alcalde de casa y corte antes de promocionar a las salas del Consejo de Castilla y del Consejo de Guerra. De hecho, parece claro que el desempeño del oficio de alcalde de casa y corte era un hito en la carrera judicial de aquellos que aspiraban a llegar al Consejo de Castilla, (Fayard, 1982: 75).

Alonso Muñoz de Otálora consiguió gracias a su cursus honorum trabar muy buenas relaciones y contraer un afortunado matrimonio con Constanza de Ontiveros y Góngora, nacida en Osuna, hija de Pedro de Ontiveros, familiar del Santo Oficio, y de doña María de Góngora y Vega. Pedro de Ontiveros se obligó a dotar a su hija con 39000 ducados. Dejando al margen la riqueza de ambas familias, una dote semejante, de menor cuantía a las otorgadas por las grandes casas aristocráticas castellanas (Rodríguez, 2010: 169), pero mucho más elevada que las que solían manejar las élites concejiles, sólo se explica por ciertos factores culturales y por los condicionantes sociales de la limpieza de sangre. María de Góngora y Vega, madre de doña Constanza Francisca de Ontiveros, emparentada con el conocido Luis de Góngora, tenía ascendencia conversa, circunstancia que saldría a relucir en las pruebas genealógicas realizadas en 1645 para la concesión de un hábito de la orden de Calatrava a Pedro de Arrese Narváez y Ontiveros. Felipe IV tuvo que escribir a su embajador en Roma para que el Santo Padre otorgara dispensa y Pedro de Arrese pudiera lucir el hábito de Calatrava5 .

3 Archivo General de Murcia (en adelante AGM). Not. 7036, fols. 49r./v. Donación de Pedro Muñoz de Otálora.

4 La visita, realizada en 1600, se conserva en el Archivo de la Universidad de Compostela. Libro de visitas reales y ordinarias. F. U., A-36, fols 21r/51v. Visita real del licenciado Alonso Muñoz de Otálora, Oidor de la Real Audiencia de Galicia.

5 Archivo Histórico Nacional (en adelante AHN). OSUNA, C.1978, D. 43. Carta de Felipe IV a Briceño Ronquillo, embajador en Roma, en la que le ordena pida a Su Santidad dispensa para que Pedro de Arrese Narváez pudiese tomar el hábito de Calatrava, a pesar de no haber probado plenamente la nobleza de su abuela materna. 
Árbol genealógico 1. Descendencia de Pedro Muñoz.

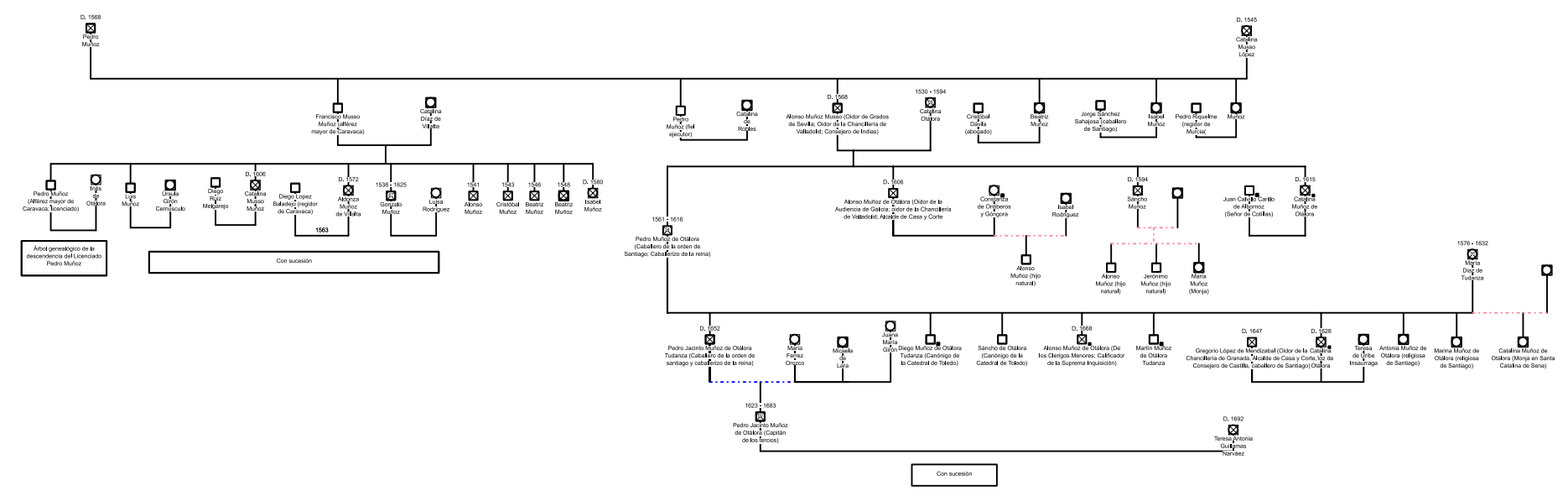

Fuente: elaboración propia.

Aunque el licenciado Alonso Muñoz de Otálora aconsejó a su hijo natural que estimase "más la virtud que todos los haberes del mundo", correspondiendo a sus "honrados ascendientes", lo cierto es que esta importante inyección patrimonial le permitió emplear recursos para el arte. Las rentas de sus juros, censos y tierras y sus salarios de alcalde de casa y corte también eran importantes. Lo cierto es que Alonso Muñoz consiguió reunir una interesante pinacoteca de temática profana y religiosa, tasada en agosto de 1606 por Francisco López, pintor del rey ${ }^{6}$. El lujo que refleja su inventario de bienes se manifestaba probablemente en los salones de recepción del primer piso de sus casas principales, lugar donde normalmente los aristócratas y oligarcas exponían las colecciones de pintura (Colomer, 2004: 138). La colección se debe, sin lugar a dudas, a la exclusiva iniciativa de Alonso Muñoz de Otálora: en el inventario de bienes de su padre, realizado en mayo de 1569, figuran una gran cantidad de joyas y objetos de oro y plata, pero tan sólo se mencionan cuatro obras de arte: una imagen de Nuestra Señora de pincel, una imagen de Nuestra Señora, con sus puertas y una cadenita de plata, una imagen del descendimiento de la Cruz de pluma y un niño Jesús de Bulto7.

El inventario de Catalina de Otálora, hija del licenciado Sancho López de Otálora, su esposa, realizado en Madrid en 1611, no se conserva, al menos en la fecha citada en los pleitos y expedientes que mantuvieron sus descendientes por los vínculos familiares ${ }^{8}$. Sin embargo, constatamos que en el inventario de bienes de Catalina Musso, madre del mencionado licenciado Alonso Muñoz, consejero de Indias, elaborado en el año $1545^{9}$, no figura ninguna obra de arte reseñable, circunstancia que evidencia que el coleccionismo no experimentó un notable auge entre las oligarquías urbanas hasta las décadas finales del siglo XVI.

No nos consta que el licenciado Alonso Muñoz encargara expresamente alguna obra a los pintores de renombre, aunque es una posibilidad que tampoco podemos descartar. En cualquier caso, lo que sí está claro es que en alguna ocasión aprovechó las almonedas para adquirir ciertas pinturas. En su testamento, redactado en 1606, menciona que tomó algunos retratos en la almoneda del conde de Alba de Liste, de los cuales debía cien ducados a la condesa $^{10}$. Tanto la biblioteca como la colección de pintura del licenciado Alonso Muñoz se conservaban en sus casas de la villa de Madrid, lugar donde residía y donde se practicaron el inventario y la tasación de sus bienes.

Entre las obras de carácter religioso destacaban, entre otras, un retrato de Santa Susana con los viejos apreciado en trescientos reales y un retrato de Santa Ana y Santiago valorado en

\footnotetext{
6 AHPNM. T. 1294, fols. 95r/109r. Tasación de bienes del licenciado Alonso Muñoz de Otálora.

7 AHN. CONSEJOS, Exp. 5, fol. 164. Inventario de bienes del licenciado Alonso Muñoz, del consejo de Indias.

8 ARChG (Archivo Real Chancillería de Granada). Caja 9081-007. Ejecutoria del pleito por los vínculos de la familia Muñoz de Otálora.

9 AHN. CONSEJOS, 25857, Exp. 5. Pieza 11. Inventario de bienes de Catalina Musso.

10 Archivo General de Simancas. C. Mercedes, 123, s.f. Testamento del licenciado Alonso Muñoz de Otálora.
} 
otros trescientos reales. La temática mitológica estaba bien representada gracias a un retrato de Venus y Adonis apreciado en doscientos reales y a un cuadro de las parcas hilando que fue tasado en treinta ducados. También había espacio para los retratos de los reyes, de los validos y de la alta nobleza: figuran, entre otros muchos, un retrato del duque de Lerma tasado en cuatrocientos reales y un cuadro de la reina de Francia apreciado en otros cuatrocientos reales. No faltaba el típico retrato de Nuestra Señora del Pópulo, virgen de especial predilección de la familia, bajo cuya advocación estaba la capilla fundada por Pedro Muñoz "el viejo" en la iglesia parroquial de El Salvador de Caravaca en torno al año 1556 (Pozo, 2002: 44).

La biblioteca que poseía el licenciado Alonso Muñoz de Otálora también era especialmente interesante y significativa, aunque la mayor parte de los libros inventariados están directamente relacionados con su actividad estudiantil y profesional y están escritos en lengua latina. Es bastante probable que las novelas, la poesía y otros libros escritos en romance nunca fueran inventariados. Abundan los libros de derecho y de cánones, así como los de teología y humanidades. Poseía unos pocos libros escritos en italiano y muchos escritos en romance, destacando las historias, las crónicas y las genealogías ${ }^{11}$. La abundante y voluminosa biblioteca del licenciado Alonso Muñoz de Otálora tiene su origen en el legado efectuado en el año 1567 por el licenciado Alonso Muñoz, su padre, consejero de Indias:

Yten, mando a Alonso Muñoz, mi hijo, ques el menor de los hijos que yo e la dicha doña Catalina de Otálora, mi muger, al pressente tenemos, todos los libros que yo tengo e tuviere al tiempo de mi muerte, de qualquier facultad que sea, con sus cassas en que están, si fuere estudiante y estudiare ${ }^{12}$.

Posteriormente compraría de Alonso de Eraso, alcalde de casa y corte, "cierta partida de libros en acomodados precios", aunque por su testamento ordenaría que se entregaran a Miguel de Eraso, hijo del mencionado alcalde, si daba el mismo dinero que había pagado por ellos. Asimismo, compró, por escritura otorgada ante el escribano Juan Ramírez, ciertos libros al conde de Alba de Liste y una copiosa librería en la almoneda de los bienes de Francisco Álvarez de Ribera, regente de Nápoles, inventariada con todo lujo de detalles en 1606. No obstante, parece que finalmente cincuenta y un volúmenes de esta última biblioteca se devolvieron a Gregorio de Orozco, a cuyo cargo estaba la almoneda, tal y como solicitó el licenciado Alonso Muñoz de Otálora en su testamento:

Declaro que compré en la almoneda del rigente Rivera una librería con condición que los libros no estuviesen sucios, estando muchos, y así se a de volver. Mando que se buelva cobrando primero lo que e gastado en enquadernaciones y rétulos y correas, que lo que esto montó dirá el retulador que vive junto a las escuelas de esta ciudad ${ }^{13}$.

Parece que finalmente la biblioteca del licenciado Alonso Muñoz de Otálora fue a parar a manos de Diego Sarmiento de Acuña, conde de Gondomar, personaje del círculo relacional de la familia. En 1606 el conde solicitó una memoria de la biblioteca a Diego González de Contreras (Real Biblioteca, P. N., 2013) y es bastante probable que posteriormente Catalina Muñoz de Otálora, hermana del licenciado y viuda del señor de Cotillas, se la vendiera, seguramente por un precio no muy inferior a los seiscientos ducados. Catalina Muñoz de Otálora mantenía unas buenas relaciones con el conde, de hecho en alguna ocasión le escribió solicitándole ayudas y favores.

Los Muñoz de Otalora afincados en Caravaca también cursaron estudios en Salamanca y en otras Universidades, tanto bachilleratos como licenciaturas, y es bastante probable que poseyeran bibliotecas de similares características, acabando tal vez finalmente en poder de los Sáenz de Navarrete o de los Uribe, descendientes directos del licenciado Pedro Muñoz. De hecho, Diego de Uribe Yarza Musso Muñoz de Otálora, marqués de San Mamés, poseyó en la segunda mitad del siglo XVIII una importante biblioteca compuesta de 291 volúmenes de materias tan variadas como la historia, las ciencias morales y literarias o la filosofía

\footnotetext{
11 AHPM. T. 1294, fols. 110r/128r. Inventario de bienes del licenciado Alonso Muñoz de Otálora.

12 AGS. CME, 123, 20. Testamento del licenciado Alonso Muñoz

13 AGS. C. Mercedes, 123, s.f. Testamento del licenciado Alonso Muñoz de Otálora.
} 
(Melgares, 1987-1989: 1713-1989). La mayor parte de los inventarios y particiones de bienes de los notarios de Caravaca del periodo moderno han desaparecido ${ }^{14}$, pero localizamos algunas pequeñas librerías y bibliotecas, como la que poseía en el siglo XVI el bachiller Matienzo o la que vendió en 1621 el doctor Luis de Morales, presbítero, a Alonso Gutiérrez de Pinilla, vecino de Cartagena, por citar tan sólo algunos ejemplos ${ }^{15}$. La más significativa, sin género de dudas, era la que vendieron en 1747 Luis José Aznar y Reina e Isabel de Mata (probablemente era la biblioteca del licenciado Mata) a Lorenzo de Amaya, cura teniente de la parroquial de El Salvador de Caravaca, en precio de 600 reales de vellón: 376 libros de derecho civil, canónico y real, de teología moral y de otras distintas materias ${ }^{16}$.

Las casas principales que los Muñoz de Otálora poseían en la villa de Caravaca estaban situadas en la denominada calle de los Melgares, uno de los principales ejes de comunicación de la villa que partían desde la iglesia parroquial de El Salvador (Sánchez, 1999: 177-182). Estaban compuestas por corrales, servidumbre de agua, bodega, vasos de tener vino y patio interior. Formaban parte del vínculo instituido en 1572 por Aldonza de Villalta ${ }^{17}$, esposa de Diego López Baladejo, e hija de Francisco Musso Muñoz, alférez mayor de la villa de Caravaca, o al menos así aparecen descritas en la toma de posesión de bienes que hicieron sus propietarios en el año 1726, aunque es probable que a principios del siglo XVII se adosaran por la delantera a otras casas propias de la familia:

Yten, digo y aclaro que yo y el dicho Diego López, mi marido, tenemos unas casas principales en esta villa de Caravaca, que alindan con la calle del camino de Mayrena y la calle de las cantarerías e Pedro Corbalán e Alonso Melgares. Y yo y el dicho Diego López, mi marido, nos abemos conbenido, para serbiçio de Dios nuestro Señor, que las dichas casas estén sienpre en uno de nuestros herederos, sin que se puedan bender ni enajenar

Las casas fueron finalmente heredadas a finales del siglo XVI por Catalina López Muñoz, hija de los fundadores y esposa de Francisco Musso Muñoz, su primo, regidor de la villa. La fábrica, por tanto, data de la primera mitad o de mediados del siglo XVI, pero la excelente portada de cantería compuesta por capiteles, cornisas, frisos y arquitrabes, y coronada por los escudos de armas de la familia interpuestos por una amplia ventana, fue construida en 1596 por el arquitecto local Juan Fernández y por el cantero Domingo Ortiz, vecino de la villa de Moratalla. Los artífices se obligaron a finales del mes de abril del citado año a hacer una portada de "cantería de piedra franca y fuerte" para las casas de Francisco Musso Muñoz de Otálora, regidor de la villa, con los siguientes elementos y características:

Antecolumnas, basas y capiteles, cornisas, arquitrabes, frisos y frontales, piçios con blasón o blasones de armas, las que el dicho don Francisco Musso tiene de sus antepasados, con sus acompañamientos de la misma piedra dicha, y que sea todo de orden dórico y jónico ${ }^{18}$.

Francisco Fernández y Domingo Ortiz se obligaron a sacar a su costa toda la piedra que fuere necesaria y a tenerla completamente terminada en un plazo máximo de seis meses. Por su parte, Francisco Musso Muñoz de Otálora se obligó a entregarles cuarenta ducados para el coste del inicio de las obras:

Y ansimismo les a de dar otros çinquenta ducados hechos y asentados los piedestales; y otros çinquenta ducados en llegado a capiteles; y otros çinquenta ducados amediado la bentana y otros çinquenta ducados acabada la ventana y la dicha obra.

El conjunto de la obra, por tanto, se acordó en un total de doscientos cuarenta ducados. La portada de la casa de los Muñoz de Otálora se construyó en un contexto de proliferación

14 AGM. Not. 7554. Fols. 21r/50v. En la partición de bienes de Fernando de Monreal Morales y Aledo se reseña una biblioteca con diferentes libros.

15 AGM. Not. 7347, fols. 37r/38v. Inventario de libros del doctor Luis de Morales. La biblioteca estaba compuesta de 123 volúmenes.

16 AGM. Not. 10390. Venta de la biblioteca de Luis José Aznar y Reina.

17 AGM. Not. 6989, s. fol. Testamento de Aldonza de Villalta.

18 AGM. Not. 7063, fols 91v/93r. Escritura de la portada de la casa de la calle de los Melgares entre Francisco Musso Muñoz de Otálora y Francisco Fernández, arquitecto. 
de fundaciones de vínculos y mayorazgos, momento en que las familias de poder de la villa de Caravaca comenzaron a adornar sus casas, sus capillas, sus ermitas y oratorios con blasones y con escudos de armas. Otras familias, como los Conejero, por ejemplo, encargaron la construcción de la portada de la casa que poseían en la calle de los Melgares en fechas más tardías, concretamente en el año 1623. El artífice sería Damián $\mathrm{Pla}^{19}$, maestro cantero que trabajó en las obras de la iglesia parroquial de El Salvador, en las del convento de carmelitas descalzas $^{20} \mathrm{y}$ en las del templo de la Santa Vera Cruz, entre otras muchas.

Árbol genealógico 2. Descendencia del licenciado Pedro Muñoz.

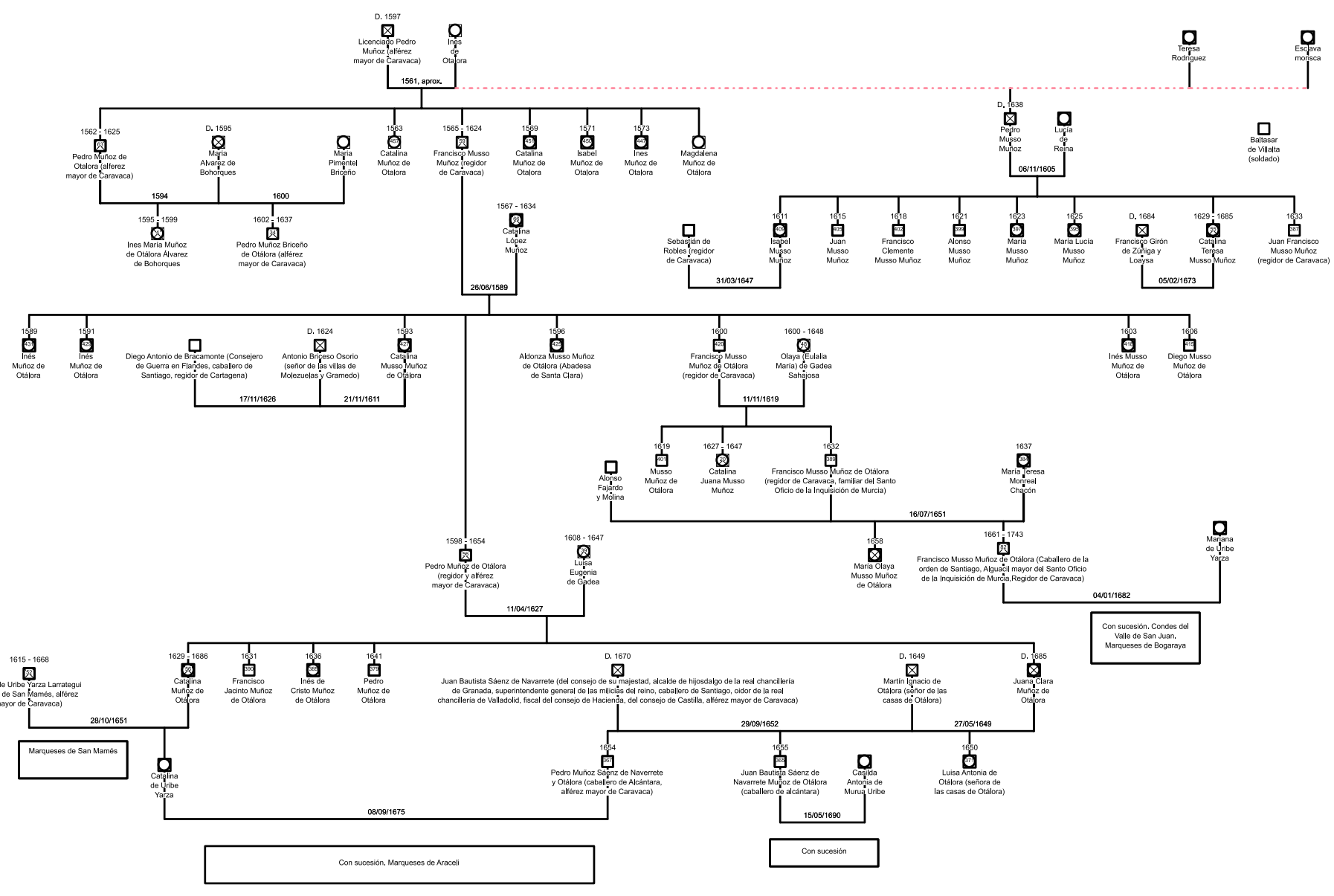

Fuente: Elaboración propia.

A mediados del siglo XVII las casas del vínculo de Aldonza de Villalta fueron heredadas por Juana Clara Muñoz de Otálora, hija de Pedro Muñoz de Otálora, alférez mayor de la villa, y de Luisa de Gadea Sahajosa. Juana Clara Muñoz de Otálora nació en Caravaca en el año 1633 y contrajo un primer matrimonio en 1649 con Martín Ignacio de Otálora, su pariente. Contraería un segundo matrimonio en 1652 con Juan Bautista Sáenz de Navarrete, caballero de la orden de Santiago. Juan Bautista Sáenz de Navarrete, consultor del Santo Oficio, hijo del secretario Juan Bautista Sáenz de Navarrete, caballero de la orden de Alcántara, y de doña María de Mena y Urrea, fue un personaje distinguido por sus servicios a la corona en las reales audiencias y en los consejos. Fue colegial en el Mayor de Cuenca de Salamanca, ${ }^{21}$ oidor y alcalde de los hijosdalgo de la Real Chancillería de Granada, oidor de la Real Chancillería de Valladolid, fiscal de millones en la sala del Consejo de Hacienda ${ }^{22}$ y ya en el año 1670 fiscal Consejo de Castilla (De Francisco, 1999: 363), cargo en el que finalmente moriría.

\footnotetext{
19 AGM. Not. 7394, fols 280v/283v. Contrato de la portada de las casas de los Conejero.

20 AGM. Not. 7328, fols. 158v/161v. Contrato de obras del convento de carmelitas descalzos.

21 AGM. Not. 7114, fols. 83r/84r. y 172r/173r. Poder para testar y testamento de Pedro Muñoz Sáenz de Navarrete.

22 Archivo de la Real Chancillería de Valladolid. Libro de actas del Real Acuerdo, Libro 166, fols. 268 r.
} 
Este matrimonio practicó un coleccionismo activo de pinturas y de obras escultóricas propio de las élites nobiliarias. Las colecciones de arte en no pocas ocasiones eran fruto de herencias, posteriormente acrecentadas mediante diversas adquisiciones. Es probable que algunas de las obras de arte que figuran en el inventario y partición de bienes de Juana Clara Muñoz de Otálora, practicado en Caravaca septiembre de $1686^{23}$, fueran heredadas o adquiridas del contador Juan Bautista Sáenz Navarrete, personaje muy cercano al aparato institucional de la monarquía y al conde duque de Olivares. En cualquier caso, aparecen inequívocamente descritos como bienes propios de Juana Clara Muñoz de Otálora, conservados en sus casas de Caravaca, las propias del vínculo instituido por Aldonza Muñoz de Villalta. Los inventarios de bienes recogen las obras de arte no solo por motivos legales y económicos, sino por otro tipo de cuestiones estrechamente relacionadas con la antigüedad y la perpetuación de la memoria del linaje (Castillo, 2018: 865-879).

El coleccionismo y el patrocinio femenino de obras de arte y culturales, practicado por las élites urbanas y nobiliarias, nos remite a una ecuación de mujeres cultivadas, con gusto por el arte y con cierto grado de autonomía con respecto a sus maridos, como evidencia el caso de Policena Spinola, marquesa de Leganés (Arroyo 2015: 2527-2538). Juana Clara Muñoz de Otálora, salvando las distancias, al igual que Policena Spinola, era una mujer de posición elevada (aunque no poseía título nobiliario), cercana a los círculos de poder de la corte y poseedora de una inmensa fortuna, tasada en una cifra cercana a los veinticuatro millones de maravedís (se incluyen los principales de censos no seguros), sin contar los cuantiosos bienes vinculados que poseía como heredera de todos los mayorazgos fundados por los Muñoces de Caravaca. Su inventario de bienes denota el lujo que rodeaba a la familia y su gusto por las obras pictóricas y escultóricas. También nos adentra en otras cuestiones que nos remiten a la representación pública de la posición y del estatus social, especialmente evidente a través de los adornos personales, de las joyas y de los ricos vestidos que lucían. Estos tipos de inventarios de bienes muestran la existencia del gusto femenino por el arte e ilustran muy bien la vida cotidiana de la mujer de la nobleza del siglo XVII, desarrollada especialmente en los ámbitos religioso, doméstico, social y privado (Castillo, 2018: 872).

Las casas principales de los Muñoz de Otálora eran un fiel reflejo del estatus de la familia: no hay que olvidar que en un mundo de apariencias marcado por el afán de visibilizar y representar públicamente el poder y la valía personal y grupal la residencia de las familias de poder se convirtieron en el medio más contundente y directo de demostración de la honorabilidad (Serrano, 2015: 1383-1395). El espacio, franqueado por la mencionada fachada barroca, contenía el típico mobiliario que decoraba las casas de las élites urbanas del siglo XVII: armarios de pino, bufetes de nogal, de caoba y de ébano, braseros, baños de pino, papeleras chapadas de ébano, escritorios de coral, ébano y marfil, arcas de pino, cofres de pino, arquetas de caoba, sillas de nogal, mesas de pino, etc. El mobiliario de Juana Clara Muñoz de Otálora no difiere en exceso del que poseían algunas otras damas tituladas de la época, ni tan siquiera en las tipologías de los materiales de construcción. Los muebles fueron apreciados por las clases acomodadas atendiendo a su singularidad, a su belleza estética o a las maderas finas y exóticas con las que se construían, convirtiéndose finalmente en un indicador de la posición social del propietario (Castillo, 2016: 55-69).

Las camas, usadas tanto por los señores de la casa como por los esclavos y criados, eran muchas y muy variadas: los criados y los esclavos dormían en los catres, en los jergones y en las denominadas camas de cordel, mientras que los dueños de las casas se reservaban camas más cómodas y lujosas, provistas de doseles que se cubrían con colgaduras, cortinas, cobertores y rodapiés. En el inventario y partición de bienes de Juana Clara Muñoz de Otálora se mencionan, entre otras muchas, dos camas que podríamos considerar ciertamente lujosas, seguramente usadas privativamente por los señores de la casa: una cama dorada de madera a lo salomónico y una cama grande de granadillo con sus cabeceras y bronces dorados con puntas y bastidores para la colgadura. El inventario describe un gran número de colgaduras de damasco y de gasa de una amplia gama de colores. Las cortinas descritas son de ante y de

23 AGM. Not. 7189, fols. 139r/253v. Inventario y partición de bienes de Juana Clara Muñoz de Otálora. 
tafetán, las almohadas de lienzo, las sábanas de lienzo, lino y cáñamo, las colchas de algodón bordadas con flores y los colchones de lienzo de Galicia y de cáñamo.

Junto al mobiliario también destacan los útiles y trastos de cocina, ordinariamente empleados en la elaboración de los alimentos que consumían los habitantes de la casa. Los Muñoz de Otálora tenían prácticamente una economía autosuficiente y producían en sus tierras todos los alimentos básicos de consumo: pan, vino y aceite, pero también frutas, legumbres y hortalizas. Sus numerosos ganados, la caza y las carnicerías públicas de la villa surtían su mesa de toda suerte de viandas. Los pescados y los salazones los adquirían en las pescaderías públicas de la villa. La nieve para mantener frescos los alimentos y las bebidas las recogían en los pozos de nieve que tenían en su hacienda de Tarragoya ${ }^{24}$. El inventario menciona almireces, calderos, perolas, peroles, calderas, chocolateras, cazos, calentadores, sartenes, graillas, badiles, tenazas, asadores, etc.

La vajilla y la cubertería eran de plata, al igual que las lujosas bandejas donde se servían las comidas. No figura descrita detalladamente en el inventario, aunque es bastante posible que se recoja genéricamente en diferentes epígrafes y partidas bajo la denominación de plata labrada. Encontramos, por ejemplo, 1187 onzas de plata en alhajas y piezas labradas, junto con otras 689 onzas de plata que se hallaron en los escaparates de la casa. Algunas de estas piezas de plata poseían una función meramente decorativa: el inventario de Juana Clara Muñoz de Otálora, por ejemplo, describe una fuente de plata que tenía grabadas las armas de los Otálora. La vajilla y cubertería de plata de Juana Clara Muñoz de Otálora no debía ser, no obstante, muy diferente de la que poseía el licenciado Alonso Muñoz de Otálora: en el inventario de sus bienes se describen cucharas, tenedores, platos, platones, saleros, azucareros, salvillas, fuentes, jarros y bacines. Lo más valioso era una salva dorada lisa que pesaba más de dos marcos y estaba tasada en cuatro ducados. Finalmente, en la mesa de los Muñoz de Otálora no faltaban las tablas de manteles de cáñamo y de lino, típicos de la villa de Caravaca, ni tampoco las servilletas de cáñamo.

Los suelos de las habitaciones principales de la casa se cubrían con alfombras de colores y las paredes se decoraban con tapices, reposteros y cuadros. En el inventario de Juana Clara Muñoz de Otálora se mencionan ocho tapices de galerías apreciados en cinco mil reales y tres reposteros con las armas de los Muñoces, empleadas seguramente para engalanar las caballerías. Los tapices en el ámbito doméstico español se encuentran en colecciones relativas a todos los grupos sociales, asociados a factores estrechamente vinculados con elementos de prestigio y de supuesta posición social del propietario, perviviendo, en muchas ocasiones, gracias a que desde los primeros momentos las grandes casas nobiliarias los agregaron a sus vínculos y mayorazgos (Ramírez, 2013: 235). Los tapices tenían un clara función decorativa, pero también poseían cierto componente utilitario: servían para protegerse y aislar las paredes del frío y del viento y en ocasiones hasta para compartimentar las estancias (Ramírez, 2012: 23-40). Algunos nobles, como el marqués de Zenete, poseían una amplia colección de tapices de temas mitológicos e históricos que adornaban sus casas y palacios. En este caso concreto, además de como elementos simbólicos de la riqueza de sus dueños, todo apunta a que se emplearon para hacer confortables las estancias de sus posesiones de Ayora... (GómezFerrer, 2010: 37).

La pinacoteca de los Muñoz de Otálora era ciertamente interesante, al igual que la imaginería. La colección de pintura de Juana Clara Muñoz de Otálora incluía tanto láminas de marfil y cobre, como tablas, lienzos, cuadros y vitelas, abundando principalmente la temática religiosa. El escribano y los tasadores que hicieron el inventario tan sólo mencionan a los autores de gran renombre: Rafael, Miguel Ángel, Tiziano, Rubens o Ribera. En lo que respecta a las obras originales de estos grandes maestros de la pintura universal, conviene destacar que la mayor parte de las pinturas presentes en el inventario son láminas en tabla o en cobre, aunque los Muñoz de Otálora también poseían lienzos de gran calidad. Cabe la ligera posibilidad de que estas obras fuesen meras copias de los originales. El engaño artístico en el siglo XVII fue ciertamente frecuente, como evidencia los casos del marqués del Carpio y del duque de Alcalá (Moran, 1984:

24 AGM. Not. 7275. fols. 623r/624r. Obligación de Miguel Martínez Zabala para hacer un pozo de nieve en la heredad de Tarragoya 
89-107), aunque parece que el tasador tenía amplios conocimientos periciales y un buen gusto artístico. Los últimos estudios sobre el mecenazgo femenino han demostrado que muchas mujeres próximas a la corte y vinculadas al estamento nobiliario ejercieron como coleccionistas y como protectoras del arte (Illán, 2016: 111). Juana Clara Muñoz de Otálora encaja perfectamente en el prototipo de mujer coleccionista. Además, en el inventario de sus obras se aprecia cierto criterio artístico a través de la presencia de particulares santos de su devoción.

Entre las pinturas destacan dos láminas en tabla de Rafael de Urbino. La primera, apreciada en cien ducados, era una "lámina en tabla de más de media vara de la prisión de Cristo Nuestro Señor de mano de Urbina, con su marco de palo santo y ébano". La segunda estaba tasada en cincuenta ducados y representaba la imagen de "Nuestra Señora con el niño en los brazos con su marco de ébano." La lámina original de Miguel Ángel estaba tasada en cien reales de a ocho, tenía un marco de ébano y representaba "el descendimiento de la cruz". En la colección de pintura de Juana Clara Muñoz de Otálora también destacaba un "lienzo de dos baras de largo y bara y media de ancho" original de Tiziano que representaba al marqués del Vasto, apreciado en tan sólo cuatro mil reales por estar maltratado. La pintura de mayor estimación y valor, al menos para el tasador, mereció el siguiente epíteto: "no tiene prezio en la estimazión". Se trataba de "una lámina de cobre de más de media vara con su marco de peral con molduras ondeadas, que es la calle del amargura", obra original de Tiziano. Fue tasada finalmente en doscientos ducados, aunque su valor artístico era mayor que su precio.

La pintura barroca tenía su máximo exponente en una lámina de tabla con marco de ébano que media poco menos de una vara que representaba la imagen de "Nuestra Señora con el Niño en los brazos" original de Rubens, tasada en cincuenta ducados. Por su parte, una lámina de cobre, con marco de ébano, original de Ribera, que representaba a "Nuestra Señora y el Niño, Santa Ana y San Juan Bautista" fue tasada en trescientos y cincuenta reales. Finalmente, el inventario reseña como obra notable "una lámina pintada en lienzo de la zena, de mano del Vasa (seguramente se trata de Bassano), original, con su marco de ébano, en zien ducados".

La colección de pintura de los Muñoz de Otálora también albergaba espacio para la representación de Nuestra Señora del Pópulo y para otras vírgenes y santos de su devoción, así como para personajes en proceso o en vías de canonización que eran tenidos en alta honra o estima por la familia. Estos eran los casos, por ejemplo, de Marina de Escobar, natural de la ciudad de Valladolid, y del jesuita Luis de la Puente, su confesor. Parece que Juana Clara Muñoz de Otálora tenía especial devoción por estos aspirantes a santos, seguramente propiciada en los tiempos en que su marido fue oidor de la Real Chancillería de Valladolid.

De hecho, dispuso por su testamento que entregaran al colegio de San Ignacio de Valladolid doscientos ducados en el supuesto de que llegasen a ser declarados santos, "para ayuda a los gastos de su fiestas" ${ }^{25}$. En el inventario de bienes y en su testamento se describe una pintura "de Nuestro Señor Jesucrhisto del traje y vestidura con que andaba el mundo, como se le apareció a la dicha señora doña María de Escovar, con el retrato de esta y del dicho padre Luis de la Puente, su confesor" que legó a Pedro Muñoz Sáenz de Navarrete, su hijo primogénito. También legaría "una pintura grande, retrato de Nuestra Señora del Sagrario de Toledo", al convento de religiosas de carmelitas descalzas de la villa de Caravaca, en cuya iglesia dispuso su enterramiento con el hábito de dicha religión.

La mayor parte de las pinturas inventariadas no reseñan ni especifican el nombre del autor, aunque seguramente no faltaban las obras de maestros locales, como Cristóbal Fernández Cuadrado, pintor y dorador, artífice de algunas de las tablas para retablos que adornaban las capillas de la iglesia mayor de la villa ${ }^{26}$. Juana Muñoz, esposa de Luis de Gadea Sahajosa, abuela materna de Juana Clara Muñoz de Otálora, también poseía una muy pequeña colección de cuadros e imágenes, probablemente de autoría de maestros locales o granadinos. Destacan tres países al temple con sus bastidores tasados en treintaiún reales y una imagen de Nuestra Señora con su marco de ébano tasada en ciento y cincuenta reales. También un

25 AGM. Not. 7189, fols 183r/189r.Testamento por poderes de Juana Clara Muñoz de Otálora.

26 AGM. Not. 7378, fols 616v/617v. Obligación de Cristóbal Fernández para hacer las tablas del retablo de la capilla de los Mora de la iglesia parroquial de El Salvador. 
cuadro grande de marco dorado, con la imagen de la Magdalena ${ }^{27}$. Es probable que algunas de estas obras las heredaran finalmente Juana Clara Muñoz de Otálora o su hermana Catalina, esposa de Diego de Uribe.

En la casa de los Muñoz de Otálora también había un reloj grande de campana, embutido en una torrecilla de madera de pino, que marcaba las horas de la jornada, del servicio y de los divinos oficios. Los Muñoz de Otálora disponían de un pequeño oratorio en sus casas con todos los ornamentos y objetos litúrgicos necesarios para realizar los rezos y decir la misa, ofrecida ordinariamente por los capellanes de la familia. El oratorio representaba la suntuosidad de la casa y de aquellos que la habitaban y suele estar presente en buena parte de las casas y palacios de la nobleza del siglo XVII (García, 2019: 9-28). El altar del oratorio se adornaba con sábanas y frontales de raso y de chamelote y se cubría con un dosel de tela. Los capellanes se revestían con casullas, estola y manípulo de raso y con albas de holanda, ornamentos que aparecen detallados en el inventario. También se describen corporales rodeados de puntas finas y paños de cálices para depositar el cáliz y la patena del oratorio, que pesaba dos libras. Se reseña, igualmente, un misal grande de cámara, diversas cruces, incluida una Cruz de Caravaca de latón para reliquias, y otros muchos objetos litúrgicos y de culto destinados a la celebración de la misa. El inventario también reseña someramente el cáliz, la patena y los ornamentos sacerdotales de la capilla de los Muñoces, así como los propios del oratorio y ermita del cortijo de Tarragoya, apreciados en 400 reales.

El inventario de bienes del licenciado Alonso Muñoz de Otálora, alcalde de casa y corte, realizado en 1606, incluye, asimismo, una gran variedad de ornamentos y objetos litúrgicos, seguramente destinados para el culto de la ermita familiar de Singla y para los oratorios privados de las casas de su morada. En lo que respecta a los objetos litúrgicos, destaca un cáliz y patena de plata sobredorada apreciados en seis ducados y un misal romano forrado en terciopelo carmesí y raso con chapas y manecillas de plata. En el apartado de los ornamentos, conviene destacar una casulla de tela de oro verde y encarnada, así como un frontal de tela de oro verde con un escudo delante que se complementaba con una frontalera de tela de oro encarnada y goteras.

Tanto la casa del vínculo de Francisco Musso, ubicada en la plaza pública de la villa, como la de los Muñoz de Otálora, situada en la calle de los Melgares, contaban desde mediados del siglo XVI con oratorio privado para celebrar la misa y los divinos oficios. Otras casas de la familia, como la que poseía Francisco Musso Muñoz de Otálora en la Puentecilla, no lo tendrían hasta principios del siglo XVIII ${ }^{28}$. Era frecuente que las familias de poder acudieran a Roma para solicitar Bula o Breve papal para conseguir privilegio para hacer un oratorio privado o licencia para fundar una ermita: así lo hicieron, por ejemplo, Francisco Musso Muñoz de Otálora y Ana María Melgarejo Afán de Rivera, marquesa viuda de Bogaraya, su descendiente directa $^{29}$. Los Muñoz de Otálora también disfrutaban de una variada colección de relicarios que ordinariamente depositaban en las capillas y oratorios familiares. Destacan, en este sentido, un relicario con un hueso de un santo tasado en veinticuatro reales, dos relicarios en forma de corazón guarnecidos con puntas de plata falsa apreciados en veinticuatro reales y otro relicario con un agnusdéi de cera que contenía diferentes reliquias. La colección de relicarios de Juana Clara Muñoz de Otálora era ciertamente abundante. Los objetos religiosos, presentes en la mayor parte de las dotes y bienes de las mujeres de cierto estatus social, deben ser interpretados como reflejo de un sentimiento inmaterial (Garrido, 2013: 735-744). Los relicarios, agnusdéi y demás objetos religiosos pueden ser considerados como muestras de la devoción y del sentimiento religioso, pero también como amuletos que eran empleados supersticiosamente para obtener favores y protección (Zamora, 2003: 527-544).

Las ermitas, las capillas, los oratorios y las casas de los Muñoz de Otálora también se adornaban con imágenes y figuras de santos de especial devoción de la familia. La colección

27 AGM. Not. 7307, fol. 773. Hijuela de bienes de Luisa de Gadea Sahajosa.

28 Archivo Municipal de Calasparra (en adelante AMCa) FCVS. CAR 5. Legajo. 5. $\mathrm{N}^{\mathrm{o}}$ 12-38. Bula de oratorio para Murcia y Caravaca. Francisco Musso Muñoz de Otálora y familia Melgarejo.

29 AMCa. FCVS. CAR. VII, 69. Breve de Su Santidad concediendo privilegio de oratorio privado a doña Ana María Melgarejo, marquesa de Bogaraya. 
de imágenes y de esculturas de Juana Clara Muñoz de Otálora parece significativa, aunque la descripción que recoge el inventario no ofrece muchos datos sobre estilos y autores. Las imágenes descritas parecen ser de bulto, obra de maestros castellanos, aunque también encontramos alguna obra napolitana: "un niño Jesús de Nápoles de pasión, con ojos postizos, lágrimas y pestañas, con su cabellera de pelo natural, peana dorada y estofada, puesto el pie sobre una calavera", apreciado en tres mil reales. Encontramos una gran variedad de imágenes: por ejemplo, un efigie de un santo cristo de marfil con cruz de ébano, un cristo crucificado de boj con la cruz de ébano, un San Antonio con hábito de los observantes, un niño Jesús con su peana y camisa de gasa, un san Juan Bautista sobre un peñasco con su arbolado dorado y estofado, etc.

Quizás lo más destacable sean tres esculturas o figuras originales del racionero Alonso de Cano, insigne artista granadino. Juan Bautista Muñoz de Navarrete ejerció de oidor y de alcalde de los hijosdalgo de la Real Chancillería de Granada, ciudad en la que sin duda Juana Clara Muñoz de Otálora debió encargar las esculturas que reseña su inventario al maestro Alonso Cano. La primera era un San Antonio de Padua con peana de peral apreciado en tres mil reales. La segunda, tasada en cinco mil reales, era un niño Jesús vestido con una camisa de gasa guarnecida de encajes y cintas de colores, con una gargantilla de aljófar y corales, sostenido en una peana chapada de ébano con adornos de plata. Por último, una imagen de Nuestra Señora de la Concepción con peana de peral tasada en cinco mil reales. La imagen y la peana, según la descripción que nos proporciona el tasador, estaban guarnecidas

con cantoneras, cogollos, remates y una luna de plata a los pies, y un sol de plata que le zircunda asta los hombros, y una corona de plata con un sol de rayos, y dos madejas de aljófar, una en los hombros que tiene seis bueltas y cuatro la de la garganta, y un pendiente en el cuello con dos diamantes, y toda ella guarnecida de flores de seda.

Juan Bautista Muñoz Sáenz de Navarrete, fiscal del consejo de Castilla, legó por su testamento a su esposa "un niño Jesús de talla de Alonso Cano y una imagen de Nuestra Señora de la Concepción" ${ }^{30}$, con toda seguridad se trata de las obras citadas en su inventario. La colección artística de Juan Bautista Muñoz Sáenz de Navarrete debía ser también ciertamente notable, tal y como refleja su testamento: entre las diversas mandas encontramos un Eccehomo en pintura legado a Luisa de Navarrete, su hermana, y una pintura del descendimiento de la Cruz cedida a Juana de los Ríos, mujer de Pedro de Medrano.

La más o menos abundante colección de esculturas e imágenes que poseía Juana Clara Muñoz de Otálora contrasta con la austeridad del licenciado Alonso Muñoz de Otálora para esta variante artística. Su inventario de bienes tan sólo recoge tres figuras: una imagen de Nuestra Señora del Pópulo y otras dos imágenes pequeñas de Nuestra Señora. Lo que sí compartían ambos, al igual que el resto de nobles y oligarcas, era su afición y buen gusto por las joyas: oro, plata, diamantes, esmeraldas, rubís, amatistas, etc. La tipología de estas piezas de adorno y ostentación personal, símbolos manifiestos del poder y del estatus, también era muy variada, aunque en los inventarios de bienes de los Muñoz de Otálora predominan sobre todo las sortijas y las cadenas. También encontramos abundantes piezas de uso más o menos exclusivamente femenino: flores de oro para el tocado, cintillos, pendientes, etc. En el inventario de bienes de Juana Clara Muñoz de Otálora destaca esencialmente una cadena de filigrana de oro tasada en doscientos cincuenta y seis pesos, mientras que en el inventario del licenciado Alonso Muñoz de Otálora llaman la atención dos arracadas de oro y diamantes tasadas en setecientos y setenta y seis reales. Entre los complementos de Juana Clara Muñoz de Otálora también destacan varios relojes, pero especialmente uno de porcelana de oro con cadena.

Las joyas y los adornos que ordinariamente usaban los poderosos eran el complemento perfecto para las ropas, los vestidos y las demás prendas de vestir. En los inventarios de bienes de los Muñoz de Otálora encontramos todo tipo de prendas, tanto femeninas como masculinas: jubones de tafetán, basquiñas, guardapiés de felpa y de chamelote, mantos, mantillas. En el

30 AHPNM. T. 11431, fols. 432r/441v. Testamento de Juan Bautista Muñoz Sáenz de Navarrete, fiscal del consejo de Castilla. 
inventario del licenciado Alonso Muñoz de Otálora destacan especialmente las garnachas de gorgueran, de paño y de raja, vestimenta propia de su oficio, usadas ordinariamente por los letrados y por las clases acomodadas, consistente en un sobre todo amplio con mangas cortas (Giorgi, 2013: 308). También las ropas de levantar de damasco y de picote de lana, así como los herreruelos, las calzas, los mantos y la ropilla. Los vestidos de las mujeres de la familia se componían ordinariamente de basquiña, ropa y jubón. El vestido era un elemento esencial que proyectaba hacia el exterior el estatus y permitía clasificar a los individuos conforme a la diferenciación social que les definía (Giorgi, 2017: 455-461). La imagen del caballero español, caracterizada por el atuendo negro y sobrio, estaba esencialmente ligada a la supremacía política del siglo XVI, desvirtuada en la centuria siguiente por el desgaste y descrédito de la monarquía, y fue objeto de continua regulación por las leyes suntuarias (Giorgi, 2017: 460).

Las mejores galas eran usadas para salir a pasear en las plazas o glorietas, ir a misa o acudir a las sesiones del concejo o del consejo. Juana Clara Muñoz de Otálora, por ejemplo, para los trayectos cortos dentro de las villas de Caravaca y de Madrid poseía una silla de manos negra que era ordinariamente servida por sus criados, mientras que para realizar desplazamientos más largos solía emplear un coche verde con seis vidrios cristalinos y cortinas y antepechos negros tirados por dos mulas. Las casas de los Muñoz de Otálora estaban provistas de cocheras para guardar los coches, carros y carruajes, que siempre fueron numerosos en la familia, al menos durante los siglos XVII y XVIII. En el inventario del licenciado Alonso Muñoz se reseña un coche y el licenciado Alonso Muñoz de Otálora, alcalde de casa y corte, compró un coche al marqués de Mondéjar en precio de cuatro mil reales, probablemente para hacer las rondas propias de su oficio, pues su uso no se prohibió hasta 1611 (López, 2004: 338).

En otras ocasiones, incluso ordenaron expresamente su construcción: en efecto, parece que el capitán Pedro Jacinto Muñoz de Otálora encargó en la segunda mitad del siglo XVII la fabricación de un coche a Francisco Galeote y a Juan de Pinto, maestros de hacer coches de la villa de Madrid $^{31}$. Y otras veces eran adquiridos por herencia: Francisco Musso Muñoz de Otálora legó por su testamento a su padre un coche y un caballo de pelo negro para su exclusivo uso y servicio ${ }^{32}$.

Durante buena parte del siglo XVI los coches fueron duramente criticados por las élites castellanas por su alto precio, "porque estimulaban la competencia suntuaria, conducían a la perdida de la cabellaría, porque afeminaban a los hombres porque propiciaban el desorden moral" (López, 2004:1 63), sin embargo pronto se convirtieron en objetos de lujo y de prestigio que mostraban el estatus, las relaciones de poder y el consumo (López 2004: 273). El acceso y uso del coche, por motivos sociales y económicos, estuvo prácticamente restringido a los estamentos privilegiados, tanto en Madrid, Caravaca o Córdoba como en otros núcleos urbanos, resultando ser una expresión y un símbolo de autoridad y de ostentación social (Aranda, 2019: 135-188.). Algo similar ocurría en otros territorios europeos y hasta en la mismísima corte papal: los coches, cada vez más ricos y pomposos, se convirtieron ya desde tiempos de Urbano VIII en artículos de prestigio y poder, hasta el extremo de ser necesario reconvenir a los cardenales por contravenir el decoro eclesiástico con el excesivo uso del lujo (Cozzo, 2019: 381-392). La distinción social y la jerarquía se mostraban, en efecto, mediante la decoración y la ornamentación de estos exclusivos medios de transporte y de recreo, convirtiéndose desde los primeros momentos en instrumentos de galantería y de cortejo para los varones y en medios de diversión, de paseo y de presunción para las mujeres, tanto en las romerías como en otro tipo de celebraciones laicas y religiosas (Fernández, 1991-1992: 105-124).

\section{EL PATROCINIO Y EL MECENAZGO DE LOS MUÑOZ DE OTÁLORA}

Los Muñoz de Otálora, como miembros del estamento nobiliario, protegieron y fomentaron la cultura: construyeron iglesias, ermitas, oratorios, retablos, ornamentos, etc. La nobleza protegió y usó la cultura como símbolo de su poder y de sus estatus, pero también como manifestación publicitaria de sus creencias y valores y como muestra del rango superior

31 AHPM. T. 30702, fols. 1r/6v. Testamento del capitán Pedro Jacinto Muñoz de Otálora.

32 AGM. Not.7485, fols. 74r/78v. Testamento de Francisco Musso Muñoz de Otálora y Uribe. 
estamental (Enciso, 2008: 55). El coleccionismo y el mecenazgo de la nobleza tenían un objetivo utilitario estrechamente relacionado con el rango social, la fama y el fortalecimiento de la propia imagen (Carrasco, 2000). La familia Muñoz de Otálora proyecto la imagen de su poder económico sufragando a sus expensas ermitas e iglesias en el campo y en la villa de Caravaca.

Pedro Muñoz de Otálora, hermano del licenciado Alonso Muñoz de Otálora, fabricó en la partida de Singla una ermita bajo la advocación de Nuestra Señora de la Concepción. La ermita, fabricada de cal y canto en las tierras del mayorazgo del licenciado Alonso Muñoz, del consejo de Indias, fue construida por Francisco Martínez, cantero, en el año 1612. El artífice se obligó a construir una ermita de cuarenta pies de largo y de diecinueve pies de ancho. Las tapias debían tener una vara de grosor, asentándose la piedra "con martillo y echando la cal necesaria, fraguada con sus aquilones". Finalmente se comprometió a levantar un campanario en uno de los aquilones de encima de la puerta. Se obligó a terminarla en un periodo de seis meses, cobrando cincuenta ducados por su trabajo. Las obras de la cubierta quedaban a cargo de Pedro Muñoz de Otálora y de los maestros que contratara. ${ }^{33}$. En 1613 la obra ya estaba terminada y la ermita disponía de ornamentos litúrgicos y de vasos sagrados para el servicio del culto divino (Pozo, 2002). En 1626 instituyó una capellanía para que los franciscanos dijeran las misas preceptivas y mandó una corona de plata, un collar de cristal y otros ornamentos para el servicio de la ermita ${ }^{34}$. La capellanía finalmente se dotaría con rentas suficientes en el año $1654^{35}$.

La familia también contribuyó con los Franciscanos en la difusión de la pasión de Cristo a través de la construcciones de ermitas del vía Crucis (Pozo y Marín, 2017: 131-141). Francisco Musso Muñoz de Otálora y Catalina López Muñoz encargaron, seguramente a Damián Pla, maestro cantero, la construcción de la duodécima estación del Vía Crucis del Calvario en el año 1617. La ermita estaba acotada por una cerca franqueada por una puerta a la que se accedía por una escalera construida en 1621 por el referido maestro ${ }^{36}$.También construyeron ermitas y oratorios en el cortijo de Tarragoya para prestar culto a los numerosos labradores que trabajaban sus tierras. Pero donde mejor se mostraría el afán de manifestar su poderío económico y su compromiso con los valores civilizatorios del Antiguo Régimen sería en la reconstrucción de la iglesia de Nuestra Señora de la Soledad, primigenia iglesia parroquial de la villa (Pozo, 1998: 18-22).

Gonzalo Muñoz, regidor de Caravaca, ordenó en 1625 que se dieran seis ducados para ayuda de la obra que se estaba haciendo en la antigua capilla que los muñoces poseían en la iglesia de Nuestra Señora de la Soledad. Ana María Íñiguez, hija de Juan Íñiguez y Luisa de Robles, mandó en 1637 que se dieran de sus bienes siete ducados para la capilla del Santo Cristo que se estaban obrando en la referida iglesia, así como otros dos más para comprar cera $^{37}$. Pedro Muñoz de Otálora comenzaría a reedificar la iglesia a sus expensas partir del referido año, incorporándola de algún modo al patronato de la capellanía y pías memorias que instituyó Pedro Muñoz Briceño, su primo hermano. También dejó algunos dineros para fundar un patronato para la procesión del Santo Entierro de Cristo.

Aunque la mayor parte de la iglesia se reedificó ex novo, parece que se aprovecharon algunos muros y algunos otros elementos de la antigua edificación, si bien la mayor parte de la piedra de la obra se extrajo de la cantera de la Encarnación y del Caravacón ${ }^{38}$. Pedro Muñoz de Otálora, primer patrono y fundador de la iglesia, la cual financió íntegramente, ${ }^{39}$ concertó la obra hasta los arcos con Juan Garzón Soriano ${ }^{40}$, maestro de cantería que posteriormente trabajaría en la portada de la iglesia de El Salvador, en precio de 44088 reales de los que parece

\footnotetext{
33 AGM. Not. 7221, fols. 3r/4r. Contrato de la ermita de Singla entre Pedro Muñoz de Otálora y Francisco Martínez, cantero.

34 AGS. CME, 130,34, s. fol. Testamento de Pedro Muñoz de Otálora, caballero de la orden de Santiago.

35 AGM. Not. 7420, fols. 180r/182v. Escritura otorgada por el padre Alonso Muñoz de Otálora, de los clérigos menores, para la dotación de la capellanía de la ermita de Singla.

36 AGM. Not. 7347, fols. 43v/46r. Contrato de las escaleras de la ermita de la reja.

37 AGM. Not. 7278, fols 1663r/1668v. Testamento de Ana María Íñiguez, hija de Juan Íñiguez y Luisa de Robles.

38 AGM. Not. 7173, fol. 77r/

9 AGM. Not. 7182, fols. 392r/401v. Cuentas de la fábrica de la iglesia.

AGM. Not. 7307, fols. 760r/765r. Testamento de Pedro Muñoz de Otálora.
} 
que a la altura de 1654 solo había recibido algo más de 9000 en "materiales y otras cosas". Posteriormente dejaría en poder de Juan Dozón, religioso y procurador de la Compañía de Jesús, otros 12764 reales de a ocho para que se continuase la obra y se hicieran ornamentos (Pozo, 1998: 22).

El Licenciado Baladejo, albacea de Pedro Muñoz de Otálora, ajustó en 1565 la obra de las cubiertas de madera con los carpinteros Sebastián de Zafra, vecino de la villa de Cehegín, Alonso Torrecilla y Juan Giménez, ambos vecinos de la villa de Caravaca, en precio de 2800 reales, comprometiéndose a acabarla en enero de $1657^{41}$. El carpintero Sebastián de la Iglesia, que al igual que Garzón también trabajó en las obras de El Salvador, además de fabricar el molde para las cornisas y los mamperlanes de las gradas de la puerta mayor, sería el encargado de ejecutar las obras del coro, incluidos los pilares, mientas que los complementarios trabajos de albañilería quedarían por cuenta de Martín de Robles, el cual se obligó en 1657 a solar de yeso la iglesia, a cubrirla de teja y a trazar las seis bóvedas que aún estaban pendientes de construcción ${ }^{42}$, comprometiéndose, asimismo, a hacer una media naranja que finalmente no se construyó.

En 1660 Diego de Uribe y Yarza, teniente de alférez mayor de la villa, yerno del patrono, concertó con el alarife Ambrosio López, vecino de la villa de Moratalla, la obra de la sacristía de la iglesia de Nuestra Señora de la Soledad ${ }^{43}$. Ambrosio López se obligó a construir dos cuartos, "el uno de dicha sacristia con reboltines de yesso y otro encima del" con su cocina y chimenea, quedando como único acceso al cuarto alto una "escalera por fuera", sin comunicación ni correspondencia con la iglesia. El alarife debía construir las paredes de cal y canto y enlucirlas de yeso por la faz interior, al igual que las de la iglesia, obligándose igualmente a realizar de ripia y teja la cubierta y a levantar un campanario de yeso "encima del estrivo de la puerta menor de la yglesia", recibiendo por su trabajo 4400 reales, cantidad que incluía, entre otras cosas menudas, los gastos ocasionados en la colocación de la campana vieja en la nueva espadaña (Martínez, 2017: 297).

No obstante, la obra no fue del agrado de los patronos de la iglesia y finalmente contrataron a Francisco García Hidalgo González de Quintana, maestro de cantería, para que construyera un nuevo campanario, el antepecho, la placeta y las gradas de la puerta mayor ${ }^{44}$ : una escalera de piedra jaspe colorado, con su pasamano de piedra franca, mamperlanes y umbral de jaspe, que facilitaría a la altura de la puerta mayor el acceso a de la placeta y de la iglesia. Por su parte, Pedro Muñoz, maestro de albañilería, vecino de la villa de Cehegín, quedaría como encargado de mudar la corriente del tejado ${ }^{45}$. Finalmente, Bernardino Ferrer construiría la reja de la venta de la sacristía ${ }^{46}$, Ginés Flores, carpintero, se encargaría de fabricar la ventana del coro, unas puertas de nogal para el osario de la iglesia, los cajones para los ornamentos y todas las puertas y ventanas de la sacristía, quedando la ejecución de las cerraduras y los aldabones reservada al cerrajero Ginés García y a cargo de Cristóbal de Toledo los restantes trabajos de carpintería ${ }^{47}$, entre los que se incluía la fabricación de una puerta de tableros y diez bancos de respaldo para el acomodo de los fieles que acudieran a la iglesia.

\section{CONCLUSIONES}

Con este artículo pretendíamos ilustrar desde las perspectivas social y artística la importancia y el auge del coleccionismo y del patrocinio artístico en el siglo XVII a través del ejemplo concreto que nos proporcionan los inventarios de bienes de la familia Muñoz de Otálora. Las colecciones de pintura, de tapices y de orfebrería no eran meros objetos decorativos,

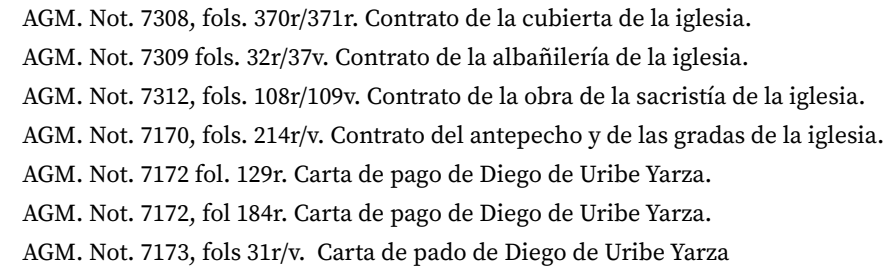


también eran un elemento esencial de la representación pública del poder económico y del estatus social de la familia. Pretendíamos, asimismo, acercarnos a través de estos inventarios de bienes a los objetos cotidianos y al mobiliario que ordinariamente adornaba las casas de las élites de poder, presentándolos como símbolos del estatus y de la posición social.

La familia Muñoz de Otálora aprovechó las rentas obtenidas de sus censos y juros, de sus negocios ganaderos y de sus heredamientos para coleccionar obras de arte y para financiar íntegramente oratorios, ermitas e iglesias. La posición social y el estatus de la familia se proyectaban a través de las manifestaciones artísticas asociadas a los escudos de armas de los patronos. Los inventarios de bienes del licenciado Alonso Muñoz de Otálora y de doña Juana Clara Muñoz de Otálora, esposa del licenciado Juan Bautista Muñoz Sáenz de Navarrete, fiscal del consejo de Castilla, nos permiten conocer el lujo y el refinamiento de la familia, así como el mobiliario asociados a las casas y palacios de las élites urbanas del siglo XVII.

La sensibilidad y el compromiso de Juana Clara Muñoz de Otálora con los valores civilizatorios del Antiguo Régimen quedan plasmados en sus interesantes colecciones de pintura y de escultura, predominando especialmente la temática religiosa. En lo que respecta a la pintura, destacan las obras de estilo renacentista, barroco y manierista atribuidas a grandes maestros de la pintura universal, tales como Rafael, Miguel Ángel, Tiziano, Rubens, Ribera o Bassano. En la colección de escultura destacan las obras atribuidas al artista granadino Alonso de Cano. En la colección del licenciado Alonso Muñoz de Otálora, acrecentada en la almoneda del conde de Alba de Liste, abundan los retratos de reyes y de aristócratas, así como la temática religiosa y mitológica. Su biblioteca nos remite a los libros propios de su oficio de letrado.

La ropa proyectaba el estatus de los individuos y permitía identificarlos conforme a su posición social: las garnachas de gorgueran, de paño y de raja, usadas cotidianamente por los letrados, indican claramente el oficio de Alonso Muñoz de Otálora, alcalde de casa y corte. Los vestidos de las mujeres, representados por basquiña, ropa y jubón, ilustran las tendencias de la moda femenina y el gusto de la oligarquía urbana y de los personajes adscritos a las instituciones reales.

Finalmente, el poder económico y el estatus de la familia queda claramente de manifiesto a través de la construcción de capillas, oratorios, ermitas e iglesias financiadas exclusivamente a sus expensas. Los escudos de armas de la familia asociados a estos edificios de carácter religioso unían lo sagrado y lo piadoso con la memoria del linaje. Al fin y al cabo era uno de los objetivos principales de las familias de poder: perpetuar la memoria.

\section{APÉNDICE DOCUMENTAL. INVENTARIO Y TASACIÓN DE LAS PINTURAS DE ALONSO MUÑOZ DE OTÁLORA}

En la villa de Madrid a los dichos catorçe días del mes de agosto del dicho año, para el efecto arriva dicho, se recivió juramento en forma devida y de derecho de Francisco López, pintor del rey, el qual lo hiço y prometió de tasar las cosas que le fueren mostradas tocantes al dicho su oficio, cada una en su valor conforme su buen entender en la forma siguiente:

Primeramente un retrato de Santa Susana en los viejos apreçiada en tresçientos reales.

Yten, un retrato grande de Nuestra Señora, el Niño Jesús y Sancta Ana y San Joan, apreçiado en duçientos reales.

Yten, un retrato a lo largo de la condesa de Alba en el campo, apreçiado en treynta ducados.

Quatro retratos de los quatro elementos apreçiado cada uno en veynte ducados.

Yten, un retrato de un niño bestido de colorado apreçiado en çien reales.

Yten, otro retrato de la princesa doña Juana apreçiado en seis ducados.

Yten, dos retratos de turco y turca apreçiado cada uno en seis ducados.

Yten, un retrato de Benus y Adonis apreçiado en duçientos reales. 
Yten, un retrato de San Gerardo apreçiado en seis ducados

Yten, un retrato de la reyna francesa, muger del rey don Felipe apreçiado en veynte ducados.

Yten, un retrato de muger grande apreçiado en seis ducados.

Yten, un retrato de la rrisa apreçiado en catorçe ducados.

Yten, un retrato del rey don Felipe segundo apreçiado en diez ducados.

Yten, un retrato de una reyna, mujer del rey don Felipe, apreçiado en seis ducados.

Yten, un retrato de un bodegón apreçiado en quatro ducados.

Yten, seis retratos de los seis meses del año apreçiados en quatro ducados.

Yten, un retrato de otro mes quando ordeñan la leche apreçiado e quatro ducados.

Yten, un retrato del duque de Florençia apreçiado en veynte ducados.

Yten, un retrato con el duque y duquesa de Alba apreçiado en ocho ducados.

Otro retrato del emperador Carlos quinto apreçiado en seis ducados.

Yten, un retrato de un niño en tabla apreçiado en seis ducados.

Yten, un retrato de Diana apreçiado en çiento y sesenta reales.

Yten, otro retrato pequeño del emperador con su quadro apreçiado en veynte reales.

Yten, otro retrato pequeño del rey don Felipe segundo apreçiado en veynte reales.

Yten, un retrato pequeño de don Joan de Austria apreçiado en veynte reales.

Yten, un retrato pequeño de la infanta apreçiado en veynte reales.

Yten, un retrato de las parcas hilando apreçiado en quatroçientos reales.

Yten, un retrato de la reyna de Françia apreçiado en quatroçientos reales.

Yten, un retrato del duque de Lerma apreçiado en quatroçientos reales.

Yten, un retrato de Orfeo con las furias roto por partes apreçiado en çien reales.

Yten, un retrato de Nuestra Señora Sancta Ana y Santiago apreçiado en tresçientos reales.

Yten, un retrato de la Samaritana junto al poço apreçiado en veynte ducados, sin marco, y con el tresçientos reales.

Yten, un retrato de las ninfas en la fuente apreçiado en catorçe ducados.

Yten, un retrato de Nuestra Señora de Monserrate en tabla apreçiado en veynte ducados

Yten, un retrato pequeño de Nuestra Señora con sus pilares de jaspe apreçiado en catorze ducados.

Yten, un retrato pequeño de Nuestra Señora de las Angustiasa apreçiado en quatro ducados.

Yten, un retrato de Nuestra Señora del Pópulo apreçiado en çinquenta reales.

Yten, un quadro pequeño de boscaje y montería apreçiado en ocho ducados.

Todas las quales cosas arriba contenidas el dicho Francisco López, pintor, tasó conforme ba declarado, cada cosa lo que le pareció balia, conforme su buen entender debajo de juramento fecho y lo firmó.

Francisco López

Ante mi, Juan del Valle. 


\section{BIBLIOGRAFÍA}

- Agulló y Cobo, M. (2003). "Un curioso coleccionista del siglo XVII: don Manuel de Porras", en Archivo español de arte, Tomo 76, $\mathrm{N}^{\circ}$ 303, pp. 235-248.

- Arroyo Martín, F. (2015).“El patrocinio artístico femenino en la edad moderna a través del caso de $\mathrm{D}^{\mathrm{a}}$ Policena Spínola, marquesa de Leganés”, en IGLESIAS RODRÍGUEZ, R. $\mathrm{M}^{\mathrm{a}}$, PÉREZ GARCÍA, R. y FERNÁNDEZ CHAVES, M. F. (coord.), Comercio y cultura en la Edad Moderna: actas de la XIII Reunión científica de la Fundación Española de Historia Moderna, Vol. 2., pp. 2527-2538.

- Astrana Marín, L. (1958). Vida ejemplar y heroica de Miguel de Cervantes Saavedra con mil documentos hasta ahora inéditos y numerosas ilustraciones y grabados de época, tomo VI, Madrid.

- Carrasco Martínez, A. (2000). Sangre, honor y privilegio: la nobleza española bajo los Austrias, Barcelona.

- Castillo Álvarez, S. (2016), "La colección de muebles y objetos decorativos de una noble sevillana: doña Catalina Ponce de León y Fernández de Córdoba (1629-1701), Holguera Cabrera, A., Prieto Ustio, E. y Uriondo Lozano, M (coord.), Coleccionismo, mecenazgo y mercado artístico en España e Iberoamérica, Universidad de Sevilla, pp. 55-69.

- Castillo Álvarez, S. (2018). "Vida cotidiana, gusto y coleccionismo femenino en la España de la Edad Moderna: doña Catalina Ponce de León (1629-1701) y el inventario y la tasación de sus bienes en 1674", en Cañestro Donoso, A. (coord.), Scripta artium in honoren prof. José Manuel Cruz Valdovinos, Vol. 2, pp. 865-879.

- Colomer, J. L. (2004). "Pautas del coleccionismo artístico nobiliario en el siglo XVII", en Arellano Ayuso, I. y Vitse, M. (coord.): Modelos de vida en la España del Siglo de Oro, Vol. 1, pp. 123-158.

- Cozzo, P. (2019). "Coches y caballos de los príncipes de la iglesia: notas de movilidad y distinción del alto clero en Italia (Siglos XVI-XIX)," en Aranda Doncel J. y Martínez Millán, J. (coord.), Movilidad cortesana y distinción: coches, tiros y caballos, Córdoba, pp. 381-392.

- Cutillas de Mora, J. M. y Montojo Montojo, V. (1998). "La nobleza de Caravaca de la Cruz en la Edad Moderna”, en Murgetana, n ${ }^{\circ}$ 97, pp. 39-61.

- De Francisco Olmos, J. Mª (1999). Los miembros del Consejo de Hacienda en el siglo XVII, Castellum, Madrid.

- De la Guardia Herrero, C. (1994). "La sala de alcaldes de casa y corte: un estudio social" en Investigaciones históricas: Época moderna y contemporánea, $\mathrm{n}^{\circ}$ 14, pp. 35-64.

- Enciso Alonso-Muñumer, I. (2008). "Nobleza y mecenazgo en la época de Cervantes", Anales cervantinos, Tomo 40: 47-61.

- Ezquerra Revilla, I. (2015). "Los alcaldes de casa y corte en tiempo de Felipe IV: unión con el Consejo y Defensa Jurisdiccional”, en Martínez Millán, J. y Hortal Muñoz, E. (coord.). La corte de Felipe IV (1621-1665), vol. 3. pp. 1961-2046.

- Fayard, J. (1982). Los miembros del consejo de Castilla (1621-1746), Madrid.

- Fernández Oblanca, J. (1991-1992). "La pasión por los coches en el siglo XVII y su reflejo cómico en los entremeses barrocos", en Archivum: Revista de la Facultad de Filología, Tomo 41-42, pp. 105-124.

- Fernández Vega, L. (1982). La Real Audiencia de Galicia: órgano de gobierno en el Antiguo Régimen (1480-1808), La Coruña.

- García Luján, J. A. (2019). "Lujo y devoción en el espacio residencial de doña Leonor Rodríguez de Fonseca y Toledo, marquesa de Campotéjar (1605-1651)", en Imafronte, n 26, pp. 9-28.

- Garibay, E. (1854). Memorias de Garibay. Memorial Histórico Español:colección de documentos, opúsculos y antigüedades que publica la Real Academia de la Historia, Tomo VII, Madrid.

- Garrido Flores, A. (2013). "Por los objetos de culto a la fe: Córdoba en el Antiguo Régimen", en Campos y Fernández de Sevilla, F. J. (coord.), Patrimonio inmaterial de la Cultura Cristiana, pp. 735-744.

- Giorgi, A. (2013). De la vanidad y de la ostentación. Imagen y representación del vestido masculino y el cambio social en España, siglos XVII-XIX, Tesis doctoral dirigida por Antonio Irigoyen López y María Concepción de la Peña Velasco. Universidad de Murcia.

- Giorgi, A. (2017). "Apariencia y movilidad social. El atuendo español en el siglo XVII", en Henarejos López, J. F. e Irigoyen López, A. (coord.), Escenarios de familia: Trayectorias, estrategias y pautas culturales, siglos XVI-XX, Universidad de Murcia, pp. 455-461.

- Gómez-Ferrer, M. (2010). "El marqués de Zenete y sus posesiones valencianas. Mentalidad 
arquitectónica y artística de un noble del Renacimiento", en Anuario del Departamento de Historia y Teoría del Arte, $\mathrm{n}^{\circ}$ 22, pp. 27-46.

- Illán Martín, M. (2006). “Coleccionismo y patronazgo artístico femenino en la Sevilla de finales del siglo XVIII”, en Lorenzana de la Puente, F. y Mateos Ascacíbar, F. J. (aut.): Arte, poder y sociedad y otros estudios sobre Extremadura, pp. 109-118.

- Jaquero Esparcia, A, (2017). "Pues es ciencia que ennoblece al que la practica". La visión del mecenazgo a través de los tratados del Siglo de Oro", en Holguera Cabrera, A., Prieto Ustio, E. y UriondoL, M. (coords.), Coleccionismo, mecenazgo y mercado artístico en España e Iberoamérica, pp. 383-396.

- López Álvarez, A. (2004). Poder, lujo y conflicto: coches, carrozas y sillas de mano en la corte de los Austrias, 1550-1700, Tesis doctoral dirigida por José Martínez Millán, Universidad Autónoma de Madrid.

- Martínez Martínez, J. A. (2017). El poder del dinero y el poder de las relaciones en el Antiguo Régimen: la trayectoria familiar de los Muñoz de Otálora, tesis doctoral dirigida por Francisco Chacón Jiménez y Juan Hernández Franco, Universidad de Murcia.

- Mainez, R. L. (1901). Cervantes y su época, Jerez de la Frontera.

- Melgares Guerrero, J. A. (1987-1989). "La biblioteca privada del "marqués de Uribe”, un ilustrado caravaqueño en las postrimerías del siglo XVIII", en Estudios románicos (ejemplar dedicado a: Homenaje al profesor Luis Rubio, nº 6, pp. 1713-1718.

- Miralles Martínez, P. (2003). "la vivienda urbana como espacio social, económico y privado, e instrumento para la movilidad social: el ejemplo de artesanos y comerciantes en la Murcia del siglo XVII", en Scripta Nova: Revista electrónica de geografía y ciencias sociales (ejempla dedicado a: la vivienda y a construcción del espacio social en la ciudad; $\mathrm{V}$ coloquio Internacional de Geografía), $\mathrm{N}^{\mathrm{o}}$ Extra 7, 146.

- Morán Turina, M. (1984). “Colecciones de particulares en Madrid en el siglo XVII”, en la Torre de los Lujanes, $\mathrm{n}^{\circ}$ 27, pp. 89-107.

- Pelorson, J. M. (1980). Les "Letrados": juristes castillans sous Phileppe III: recherches sur leur place dans la societé, la cultura et l'État, Universidad de Poitiers, Poitiers.

- Pozo Martínez, I. (2002). "La iglesia parroquial del Salvador, Caravaca (Murcia)", Murgetana, $\mathrm{n}^{\circ}$ 106, 2002 págs. 37-67

- Pozo Martínez, I. (1998). "Notas y precisiones sobre la construcción de la iglesia del Salvador y la de Nuestra Señora de la Soledad”, Revista de Fiestas de la Santa Vera Cruz, Caravaca, pp. 18-22.

- Pozo Martínez, I. (2002). Ermitas rurales de Caravaca de la Cruz, Cajamurcia, Murcia.

- Pozo Martínez, I. y Marín Sánchez, R. (2017). "Los Franciscanos y el Vía Crucis de Caravaca," Revista de Fiesta de la Santa Vera Cruz de Caravaca, Caravaca, pp. 131-141.

- Ramírez Ruiz, V. (2012). "Función de las tapicerías en la corte: s. XVII", en Res Mobilis: Revista internacional de investigación en mobiliario y objetos decorativos, vol. $1 . \mathrm{N}^{\circ} 1, \mathrm{pp} .23-40$.

- Ramírez Ruiz, V. (2013). Las tapicerías en las colecciones de la nobleza española del siglo XVII. Tesis doctoral dirigida por Guy Delmarcel, Madrid, Universidad Complutense de Madrid.

- Real Biblioteca, P. N. (2013) "Ex BIbliotheca Gondomariensi. Libros de Luis de Castilla (ca. 1540-1618) en la Casa del Sol”, en Avisos. Noticias de la Real Biblioteca, Vol. XIX, 70.

- Rodríguez Pérez, R. A. (2010). Un linaje aristocrático en la España de los Habsburgo: los marqueses de los Vélez (1477-1597), Universidad de Murcia, Tesis doctoral.

- Sánchez Romero, G. (1999). "El influjo de lo religioso en el urbanismo caravaqueño en la Edad Moderna" en El culto a la Santísima y Vera Cruz de Caravaca y el urbanismo en Caravaca y su término municipal, Universidad de Murcia, Murcia, pp. 177-182.

- Serrano Márquez, N. (2015): "Familia, ascenso social e imagen del poder: el palacio de los condes de Santa Ana de Lucena (siglo XVIII)", en Iglesias Rodríguez, R. Ma , Pérez García, R. y Fernández Chaves, M. F. (coord.), Comercio y cultura en la Edad Moderna: actas de la XIII Reunión científica de la Fundación Española de Historia Moderna, Vol. 2., pp. 1383-1395

- Ureña Uceda, A. (1998). "La pintura andaluza en el coleccionismo de los siglos XVII y XVIII", en Cuadernos de arte e iconografía, Tomo 7, n 13, pp. 99-148.

- Zamora Acosta, E. (2003). "Aproximación a la religiosidad popular en el mundo urbano: el culto a los santos en la ciudad de Sevilla”, en Buxó Rey, M. J., Rodríguez Becerra, S., Y Álvarez y Santaló, L. C. (coord.), La religiosidad Popular, pp. 527-544. 